\title{
Introduction of the American Pediatric Society's 2006 John Howland Award Recipient, Kurt Hirschhorn, M.D.
}

\author{
FREDERICK J. SUCHY \\ Department of Pediatrics, Mount Sinai School of Medicine of New York University, New York, New York, 10029
}

$\mathrm{I}_{\mathrm{H}}^{\mathrm{t}}$ $\mathrm{t}$ is a great personal honor and pleasure to introduce Kurt Hirschhorn as the 2006 recipient of the John Howland Award (Fig. 1). I have been associated with Kurt now for almost 10 years. He has been a valued advisor, friend, and confidant during this time as I matured as a department chair.

Kurt was born in Vienna, Austria, on May 18, 1926. Thus, this honor is quite fitting as coming close to his 80th birthday. Kurt does not recall his birth weight other than it being quite average. His father, Emanuel, had dual degrees in law and business administration and worked in the lumber industry in Europe. His mother, Helen, seemed to focus her attention on raising her son, their only child (Fig. 2A). Kurt's two main avocations growing up were mathematics and music. His parents were not musical but felt like he should take piano lessons like any other normal child in Vienna at the time. An uncle who was a professor at the University of Vienna nurtured his interest in mathematics. Another uncle was a physician and a professor of anatomy. As he approached high school age, he began to view medicine as a possible career path. Kurt described his life as idyllic until the age of $11 \frac{1}{2}$, when the Nazis invaded Austria in early 1938. He was immediately expelled from an elite public school and forced into a school that was set up for Jewish students. His father was imprisoned because he was Jewish and active in the social democratic party. His business was confiscated. His mother was eventually able to obtain a 2 -wk transit visa to Switzerland and, through family contacts, secure the release of Kurt's father from prison. In their journey to Zurich by train, they were stopped at the border and searched. At that time, people leaving Austria were not allowed to have any valuables and no more than 10 marks in cash. They were threatened with arrest because Kurt had insisted on bringing along his prized stamp collection, which Nazi officials felt might be valuable. One of the Swiss border guards decided that this was just a child's stamp collection and

Received May 31, 2006; accepted June 4, 2006.

Correspondence: Frederick J Suchy, M.D., Herbert H. Lehman Professor of Pediatrics and Chair, Department of Pediatrics, Box 1198, Mount Sinai School of Medicine of New York University, One Gustave L. Levy Place, New York, NY 10029-6574; e-mail: frederick.suchy@mssm.edu

Presented at the 2006 Annual Meeting of the Pediatric Academic Societies, San Francisco, CA.

DOI: $10.1203 / 01 . p d r .0000233022 .75323 .6 a$ allowed the family to come into the country. Despite only having a 2-wk visa, the family was resourceful enough to stay in Zurich for $10 \mathrm{mo}$. They eventually got a visa to England and remained there for approximately $1 \mathrm{y}$. They had a goal of immigrating to the United States and were allowed to board a ship in 1940. The convoy that brought them across the Atlantic initially had 40 ships, 3 of which were lost to Nazi torpedoes. Kurt remembers many other close encounters at what turned out to be the height of the U-boat predation.

The family landed in New York City and after 3 mo was resettled in Pittsburgh. Kurt entered an academically rigorous public high school where he was inspired by two teachers to excel in chemistry and biology. He graduated at the age of $171 / 2$ and completed one term as a chemistry major at the University of Pittsburgh. Even with World War II still raging, he was entitled to a military deferment based upon his intent to enter science or medicine but as soon as he turned 18 he volunteered for the army. He mentioned that he felt that he had a debt to the country that had taken him in and an obligation to family and friends who were left behind to suffer in Europe. As a culture shock for the young scholar, he was assigned to Fort Bragg, $\mathrm{NC}$, for basic training and later for instruction in the artillery. He was initially appointed as a forward observer in the artillery, which was quite sobering for Kurt as he learned that this job has the highest mortality of any in the U.S. Army. Casualities were as likely to result from friendly fire as from the enemy. Fortunately, the war in Europe was winding down. He served for $3 \mathrm{y}$ in the artillery, the military court system, and military intelligence, and returned to New York City in 1947. By then his family had also moved to New York. He enrolled at New York University and, taking at least 26 credits per semester, was able to graduate in $2 \frac{1}{2} \mathrm{y}$ with a major in German literature and a minor in chemistry. In applying to medical school, he was told by several Ivy League institutions that they had already met their quota for Jewish students, but was accepted to New York University School of Medicine. Kurt was involved in clinical research throughout his medical school days working with the eminent researcher John Murray Steele. Kurt's initial paper, published in Circulation, focused on methods to measure peripheral blood flow. It was also notable that Kurt met his life-long love and colleague Rochelle while he 


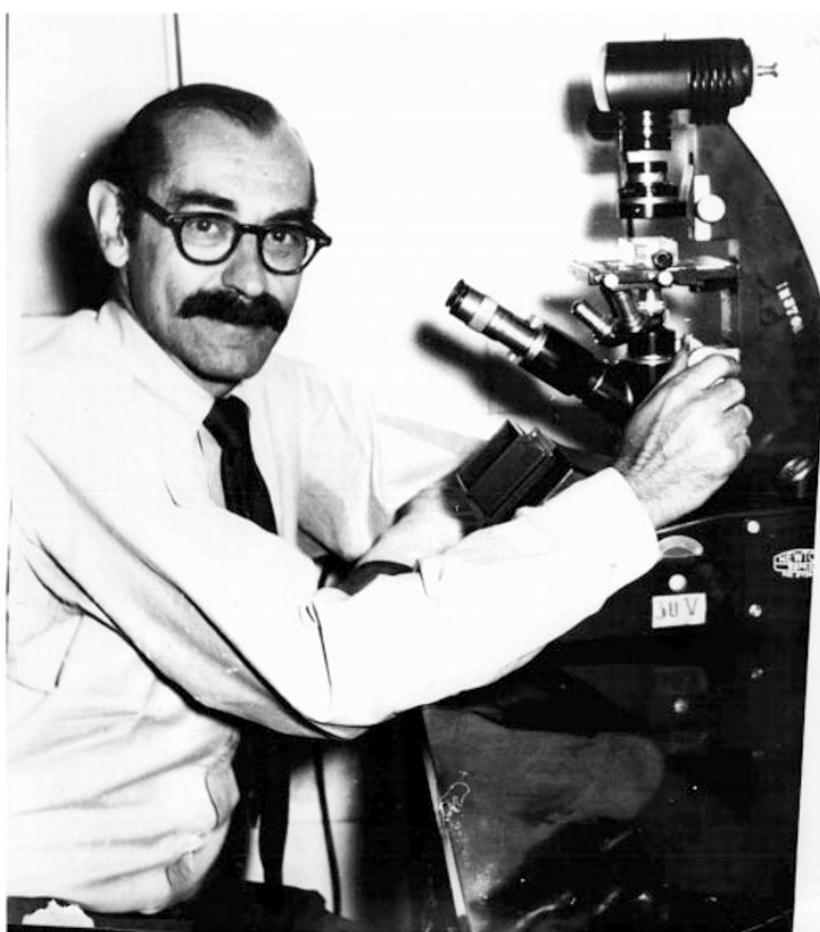

Figure 1. Dr. Kurt Hirschhorn.

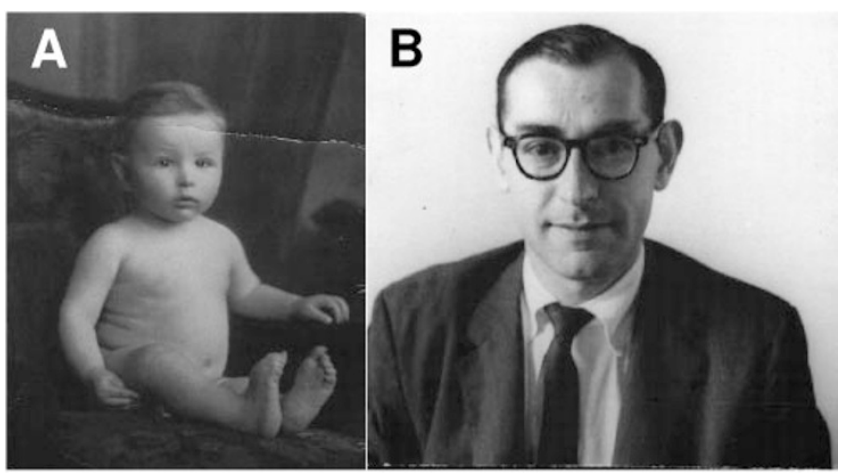

Figure 2. (A) Dr. Hirschhorn as an infant. (B) Dr. Hirschhorn as a young physician/scientist.

was junior medical student and she was a senior student at Barnard College. They were married 5 mo later.

Kurt graduated from NYU in 1954. He applied for residency in internal medicine to only two institutions, Bellevue and Mount Sinai. Both were to have a major influence on his career. He was warned that the faculty at Mount Sinai was too arrogant and therefore decided to comfortably remain at Bellevue for his residency. Following $2 \mathrm{y}$ as a house officer, Kurt was accepted into a metabolism fellowship run by the noted investigator Charles Wilkinson. His early work with Wilkinson focused on hyperlipidemia and stimulated his initial foray into genetics. Kurt decided that more intensive, formal training in genetics was in order, so he got a master's degree in genetics from NYU and then he and Rochelle traveled to Uppsala, Sweden, to study at the Institute of Human Genetics under the mentorship of Marco Fraccaro. He continued to study hyperlipidemia as a paradigm for genetic disease. During this year, he learned a number of important techniques including tissue culture and completed the work that was eventually published in Science in 1959 on the incidence of familial hyperlipidemia.

Kurt returned to NYU and was appointed an assistant professor in 1958. At that time, Rochelle began her internship at Bellevue. At NYU, Kurt's interest began to diverge from hyperlipidemia to more general issues in human genetics (Fig. $2 B)$. One notable example was the description of the $4 \mathrm{p}^{-}$ syndrome, later known as the Wolf-Hirschhorn syndrome. He also made some very important fundamental contributions in immunology. I was astounded to learn that Kurt and his colleagues were the first to discover the mixed lymphocyte response, which is still a frequently used assay in immunology and one of the few things I remember from my medical school immunology course. He noted that when lymphocytes of different individuals were cultured together they underwent proliferation (1). These studies also led to the development of the concepts that small lymphocytes are memory and not end cells and that lymphocyte interaction in vitro could be a powerful test of histocompatibility necessary for organ transplantation (2). These seminal studies where published by Kurt in Science and subsequently became Citation Classics. In reflecting on this work 20 y later, when a 1963 Science paper became a Citation Classic, Kurt commented that "I am personally convinced that the work was done and that it succeeded because as geneticists we naively pursued an observation in another discipline immunology without the full realization that our result would question established dogma. In the years since I have consistently encouraged students and fellows not to fear a fresh viewpoint and to use their techniques in other fields. I believe that this paper has frequently been cited because our findings attracted many proper immunologists to use the simple technique of cell culture for the study of numerous immunologic phenomena." (3)

In addition to performing this groundbreaking research, Kurt also ran the genetics and lipid clinics at Bellevue Hospital. By the mid-1960s, Kurt's research group had grown to 14 people who were crammed into 800 square feet. He recalls that NYU was unwilling to provide additional space and that his research team was required to work in shifts. Kurt decided that it was time to move on and had many offers around the country. He had already developed a friendship with Horace Hodes, another Howland awardee, at Mount Sinai. Hodes frequently called Kurt for advice regarding genetics and for occasional consults. In 1966, the Mount Sinai School of Medicine was founded and Kurt became the first outside recruit to this new institution. He was offered the position as a tenured professor of pediatrics and given the opportunity to set up a section of medical genetics within the Department of Pediatrics.

Although not trained in pediatrics, Kurt rapidly acquired an expansive knowledge of the field. Dr. Hodes would later describe him as "one of the best pediatricians I have ever known." Kurt's laboratory over the next $10 \mathrm{y}$ was at the peak of productivity. He was able to obtain both center and training grants from the National Institutes of Health. A key finding during this period was the description of the inherited susceptibility to chromosome breakage in Fanconi anemia, another Citation Classic (4). He continued to refine techniques for 
prenatal chromosome analysis, identified chromosome abnormalities associated with multiple aborters, defined problems in prenatal diagnosis resulting from chromosome mosaicism, demonstrated the clinical usefulness of chromosomal banding in exact characterization of structural chromosomal abnormalities, and contributed many papers on the biochemical and genetic findings in fucosidosis and other inborn errors of metabolism.

In 1976, Dr. Hodes stepped down as chair of pediatrics and Kurt became interim chair and then permanent chair in 1977 after a national search. The department at that time had only 15 full-time faculty, about half of whom were in the section of genetics. Within $5 \mathrm{y}$, the full-time faculty had grown to 50 members and the residency tripled to 36 house staff. About half of his trainees went on to hold full-time positions in academic medicine. Many National Institutes of Health grants followed. Bob Desnick was recruited from the University of Minnesota to head Kurt's beloved section of genetics.

On the national scene, Kurt is a member of the Institute of Medicine and a founding member of the American Board of Medical Genetics and the American College of Medical Genetics. He has also served as the president of the American Society of Human Genetics. While serving on the executive Committee of the Association of Medical School Pediatric Department Chairs, he had an important role with his colleagues in establishing the very successful Pediatric Scientist Development Program. Kurt has long maintained an interest in medical ethics and is a founder of The Hastings Center, the premier organization concerned with biomedical ethics. Therefore, it is no accident that several of the early Hastings position papers, published in the New England Journal of Medicine with Kurt as a signatory, discussed the ethics of prenatal diagnosis and genetic screening.

Kurt stepped down as chair of pediatrics in 1995. As part of his legacy, he had a critical role in convincing the institution to support a separate Department of Human Genetics chaired by Dr. Robert Desnick, which remains closely aligned with the Department of Pediatrics. To this day, after $11 \mathrm{y}$, his job description may have changed, but not his level of activity. He has continued to teach students and residents, serve on important committees, run the cytogenetics laboratory, and conduct research with the support of a grant from the March of Dimes. $\mathrm{He}$ is particularly proud of an influential and highly cited 2002 paper published in Genetics in Medicine with his son Joel, an assistant professor of pediatrics at Harvard and winner of the 2004 Young Investigator Award from the SPR, on a comprehensive and critical review of the validity of genetic association studies. In observing Kurt in action for the past decade, I suspect we have not seen the last of his contributions to pediatrics and human genetics. Colleagues of the Pediatric Academic Societies, I am proud to present the 2006 John Howland Award recipient, Dr. Kurt Hirschhorn.

\section{REFERENCES}

1. Hirschhorn K, Bach F, Kolodny RL, Firschein IL, Hashem N 1963 Immune response and mitosis of human peripheral blood lymphocytes in vitro. Science 142:1185-1187

2. Bach F, Hirschhorn K 1964 Lymphocyte interaction: a potential histocompatibility test in vitro. Science 143:813-814

3. Hirschhorn K 1983 This week's citation classic. Curr Contents 30:20

4. Swift MR, Hirschhorn K 1966 Fanconi's anemia. Inherited susceptibility to chromosome breakage in various tissues. Ann Intern Med 65:496-503 